\title{
Distribution of Lymnaeidae (Mollusca: Pulmonata), intermediate snail hosts of Fasciola hepatica in Venezuela
}

\author{
JP Pointier', O Noya ${ }^{2}$, B Alarcón de Noya ${ }^{2}$, A Théron¹/+ \\ 'UMR 5244 CNRS-EPHE-UPVD, Université de Perpignan, Via Domitia, 52 avenue Paul Alduy, 66860 Perpignan Cedex, France \\ ${ }^{2}$ Instituto de Medicina Tropical, Universidad Central de Venezuela, Caracas, Venezuela
}

\begin{abstract}
An extensive malacological survey was carried out between 2005-2009 in order to clarify the exact number of lymnaeid species which may be intermediate hosts of Fasciola hepatica in Venezuela. Four species were discovered during this survey, including two local species: Lymnaea cubensis and Lymnaea cousini and two exotic species: Lymnaea truncatula and Lymnaea columella. The most common local species was L. cubensis which was found at 16 out of the 298 sampling sites. This species has a large distribution area throughout the Northern part of Venezuela and was encountered from sea level to an altitude of 1,802 $\mathrm{m}$ in state of Trujillo. The second local species L. cousini was collected at only two sites of the Andean Region at altitudes of 3,550 $\mathrm{m}$ and $4,040 \mathrm{~m}$, respectively. The European L. truncatula was found at 24 sites all located in the states of Mérida and Táchira at an altitude varying between 1,540-4,000 $\mathrm{m}$. The respective distribution areas of $\mathrm{L}$. cubensis and $\mathrm{L}$. truncatula do not appear to overlap, but more detailed malacological surveys are needed. The fourth lymnaeid species, L. columella was collected in a canal from Mérida at an altitude of 1,929 $\mathrm{m}$ and in an irrigation canal from the state of Guárico, at an altitude of $63 \mathrm{~m}$. The role of these four lymnaeid species in the transmission of fascioliasis in Venezuela is discussed.
\end{abstract}

Key words: Lymnaeidae - Venezuela - distribution - fascioliasis

Fascioliasis is a parasitosis mainly infecting cattle, but it is now considered to be an emergent disease in humans in many countries over the world (Mas-Coma 2005). In the New World, it is considered as a serious health problem in several Andean countries. Bolivia is even described as a hyperendemic area and one of its epidemiological characteristics is its very high altitude at more than 4,000 $\mathrm{m}$ (Esteban et al. 1999, Mas-Coma et al. 1999). The timing of the emergence of human foci in the Altiplano Region corresponds to the invasion by the European intermediate snail host Lymnaea truncatula (Jabbour-Zahab et al. 1997, Meunier et al. 2001). In Venezuela, human fascioliasis was first reported in 1910 and only eight sporadic cases were detected in the following decades (Risquez 1929 , Rodríguez \& González 1975, Abdul-Hadi et al. 1996, Scorza et al. 1999, Incani et al. 2002, Alarcón de Noya et al. 2006). However, in 2005 five children belonging to the same family were detected with fascioliasis in Timotes, in the Venezuelan Andes, at an altitude of 2,230 m (Alarcón de Noya et al. 2007). The same year a malacological survey carried out in the Timotes area found only a single lymnaeid species, the European L. truncatula. In this paper we present the results of an extensive malacological survey which was carried out

Financial support: ECOS-Nord (V06A01), Instituto de Altos Estudios en Salud Pública Dr. Arnoldo Gabaldón

+ Corresponding author: theron@univ-perp.fr

Received 9 January 2009

Accepted 19 March 2009 between 2005-2009 in order to clarify the exact number of lymnaeid species which may be intermediate hosts of Fasciola hepatica in Venezuela and to determine their current distribution throughout the country.

A malacological survey was carried out between 2005-2009 across the whole country. A total of 298 sites were sampled (see the inserts in the maps showing all the sampling sites). Snails were sampled from different vegetation either by hand or sampled using a scoop mounted with a wooden handle, depending on the type of site. These sites include the following main habitat types: springs, ditches, brooks, canals, rivers, swamps, tanks, ponds and lakes. Following field collection lymnaeid snails were allowed to relax overnight using menthol. They were then immersed for $40 \mathrm{~s}$ in water at $70^{\circ} \mathrm{C}$, from which they were transferred to water at RT. The soft parts were drawn from the shell with small forceps and fixed in slightly modified Railliet-Henry fluid (distilled water $930 \mathrm{~mL}$, sodium chloride $6 \mathrm{~g}$, formalin 50 $\mathrm{mL}$, glacial acetic acid $20 \mathrm{~mL}$ ). Shells were measured to the nearest $1 \mathrm{~mm}$ using callipers. Snails preserved in Railliet Henry's fluid were dissected under a stereoscopic microscope and drawings of the reproductive system were made using a camera lucida attachment. Snails were identified according to conchological and anatomical characteristics (Paraense 1976, 1982, 1984, 1995, Brown 1994, Pointier et al. 2004, 2007).

Four lymnaeid species were discovered during this survey in Venezuela, including two local species, Lymnaea cubensis L. Pfeiffer, 1839 and Lymnaea cousini Jousseaume, 1887 and two exotic species L. truncatula (Müller, 1774) and Lymnaea columella Say, 1817 (Fig. 1).

The most common local species was L. cubensis which was found at 16 out of the 298 sampling sites. These 16 sites include six ditches, three canals, three 
swamps, two brooks, one river and one spring (Table I). L. cubensis has a large distribution area throughout the northern part of Venezuela from the oriental states of Sucre and Monagas to the occidental state of Trujillo (Fig. 2). This lymnaeid snail was encountered from sea level

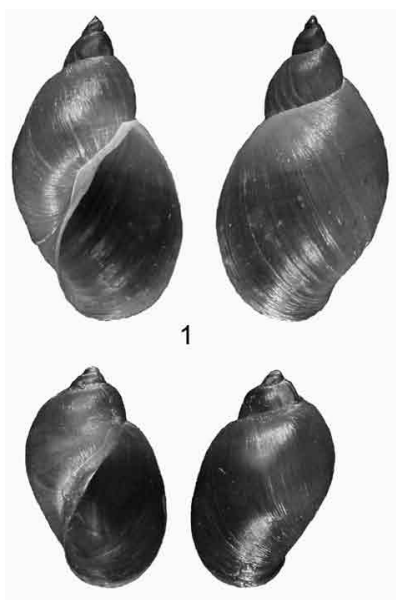

3

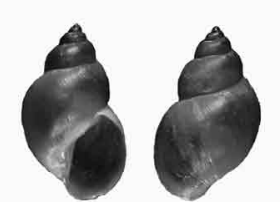

5

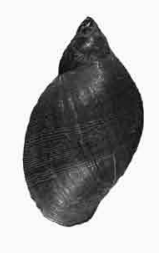

2

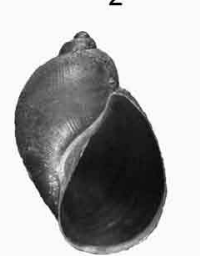

4

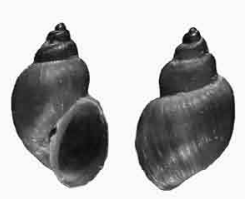

6
Fig. 1: shells of the four lymnaeids found in Venezuela between 20052009. 1: Lymnaea columella from Güigüe, state of Carabobo; 2: L. columella from El Valle, state of Mérida, showing characteristic spiral ridges of the periostracum; 3: Lymnaea cousini from Mucubaji Lake, Mérida; 4: L. cousini from Paso el Condor, Mérida; 5: Lymnaea cubensis from La Linda, Carabobo; 6: Lymnaea truncatula from Mucuchies, Mérida.
(Hato Rio de Agua, state of Sucre) to an altitude of 1,802 $\mathrm{m}$ in Trujillo (Mesa de Esnujaque) (Table I). Adult shells measured 6-10 $\mathrm{mm}$ and showed a large amount of variability. The anatomy of the reproductive system has two main reliable characters (Samadi et al. 2000): (i) small and ovoid-shaped prostate gland and (ii) a penis sheath about as long or smaller than the preputium (Fig. 3).

A second local lymnaeid species $L$. cousini was reported for the first time in 2003 in Mucubaji Lake, state of Mérida, at an altitude of 3,550 m (N8 ${ }^{\circ} 47^{\prime} 51.8^{\prime \prime}$ W7049'32.4") (Pointier et al. 2004). Three years later in 2006 this species was discovered in a small ditch in the Paso el Condor area, Mérida, at an altitude of 4,040 m (N8 ${ }^{\circ} 50^{\prime} 38.2^{\prime \prime}$ W70 49 '33.9') (Fig. 4). Adult shells of L. cousini vary between $6.6-9.3 \mathrm{~mm}$ in heigth and have a large aperture and inflated body whorls separated by deep sutures (Fig. 1). These sizes are smaller than those from the original description of L. cousini by Jousseaume (1887) but the qualitative shell characters agree perfectly with those originally described. The anatomy of the reproductive system of the Venezuelan specimens is similar to that described by Paraense (1995) for topotypic specimens from Ecuador and has reliable characters: (i) a renal tube showing two distinct flexures of the ureter; (ii) a vagina with a bulbous appearance due to local thickening; (iii) a flat spermiduct with a granular surface; (iv) a prostate with the same granular appearance and a fissure formed by the folding of its left margin and (v) a penis sheath a little longer than the preputium (Fig. 5).

A third lymnaeid species, the European L. truncatula found at 24 sites all located in Mérida and Táchira at an altitude varying between 1,540-4,000 $\mathrm{m}$ (Table II). This lymnaeid snail was found in 17 ditches, three ponds, one artificial tank, one brook, one swamp and one canal (Table II). Shells of L. truncatula are indistinguishable from those of L. cubensis (Samadi et al. 2000) (Fig. 1). The most relevant anatomical characters

TABLE I

Information on the 16 sites with Lymnaea cubensis sampled in Venezuela between 2005-2009

\begin{tabular}{|c|c|c|c|c|c|}
\hline Population name & State & Habitat & Coordinates & Coordinates & $\begin{array}{l}\text { Altitude } \\
\text { (m) }\end{array}$ \\
\hline Finca 4M Tucacas & Falcón & ditch & N1046 & W68 $24^{\prime}$ & 30 \\
\hline Finca 13 el Papelon & Falcón & swamp & N104’38.5' & W709'17’' & 416 \\
\hline Churuguara & Falcón & canal & $\mathrm{N} 10^{\circ} 48^{\prime} 48.1^{\prime \prime}$ & W69'32’34.8', & 902 \\
\hline La Quebradita Sanare & Lara & spring & N944’7.5', & W6040’3.8'” & 1,307 \\
\hline Carora & Lara & brook & N109'5.1'” & W70³’53.6”' & 425 \\
\hline El Peñon & Lara & canal & N941'47.4', & 6947'9.6’' & 757 \\
\hline Quebrada Negra & Lara & ditch & $\mathrm{N} 9^{\circ} 28^{\prime} 33.5^{\prime \prime}$ & W6957’29.7', & 926 \\
\hline Boca del Monte & Trujillo & ditch & N9¹7'55.1' & $\mathrm{W} 70^{\circ} 10^{\prime} 39.5^{\prime \prime}$ & 1,466 \\
\hline Visugui & Trujillo & ditch & N9 ${ }^{\circ} 30.5^{\prime \prime}$ & $\mathrm{W} 70^{\circ} 21^{\prime} 48.5^{\prime \prime}$ & 1,652 \\
\hline Mesa de Esnujaque & Trujillo & ditch & N9²'18.9’’ & $\mathrm{W} 70^{\circ} 42^{\prime} 58.1^{\prime \prime}$ & 1,802 \\
\hline Boqueron & Yaracuy & ditch & N10³4'11.4', & W68 $47^{\prime} 7.1^{\prime \prime}$ & 92 \\
\hline El Porvenir & Yaracuy & swamp & $\mathrm{N} 10^{\circ} 32^{\prime} 2.5^{\prime \prime}$ & W68 $49^{\prime} 58.7^{\prime \prime}$ & 129 \\
\hline Hato Rio de Agua & Sucre & swamp & N10³4'48.2”' & W6259'21.6"' & 7 \\
\hline San Mateo & Aragua & canal & N10¹2'45.6" & $\mathrm{W} 67^{\circ} 24^{\prime} 52.1^{\prime \prime}$ & 477 \\
\hline Caripe Colorado & Monagas & river & N10¹2’39’' & W6326'28', & 811 \\
\hline Caripe Teresen & Monagas & brook & N10¹1'25. '”, & $\mathrm{W} 63^{\circ} 28^{\prime} 3.1^{\prime \prime}$ & 814 \\
\hline
\end{tabular}




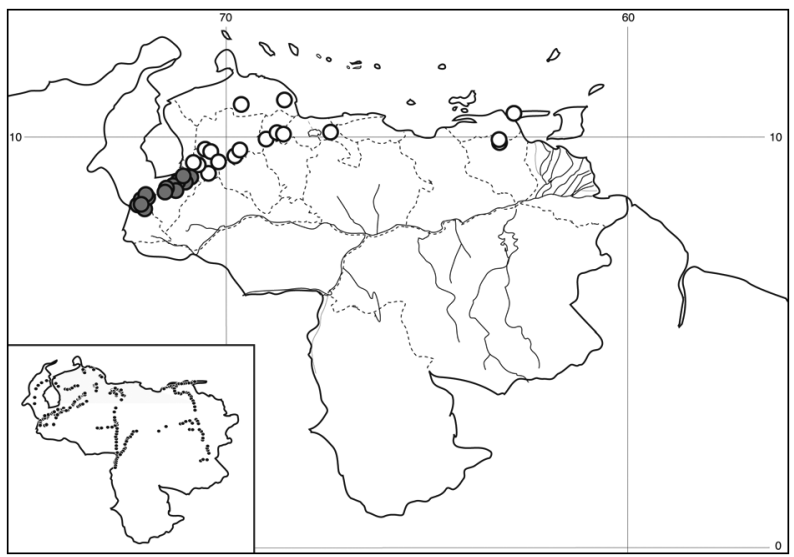

Fig. 2: distribution map of Lymnaea cubensis (white circles) and Lymnaea truncatula (grey circles). Insert on the map shows all the sampling sites carried out between 2005-2009.

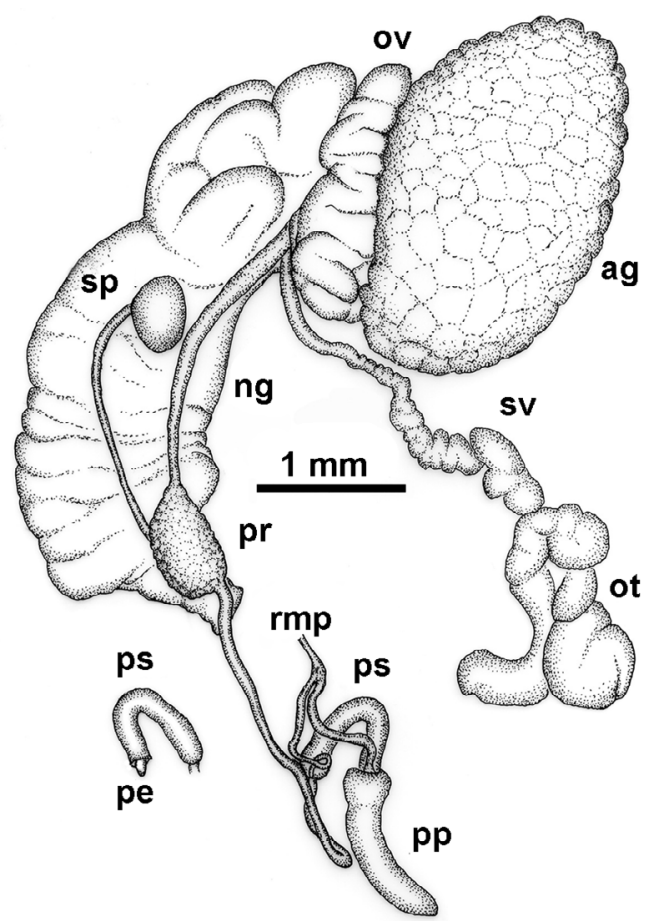

Fig. 3: anatomy of the reproductive system of Lymnaea cubensis from San Mateo, state of Aragua; ag: albumen gland; ng: nidamental gland; ot: ovotestis; ov: oviduct; pe: penis; pp: preputium; pr: prostate; ps: penis sheath; rmp: retractor muscle of penial complex; sp: spermatheca; sv: seminal vesicle.

are the size and shape of the prostate gland and the relative lengths of the penis sheath and preputium: in $L$. truncatula, the prostate is much bigger and pear-shaped and the penis sheath is much shorter than the preputium (Fig. 6); in L. cubensis, the prostate is smaller and ovoid and the penis sheath a little shorter or about the same length as the preputium (Fig. 3).

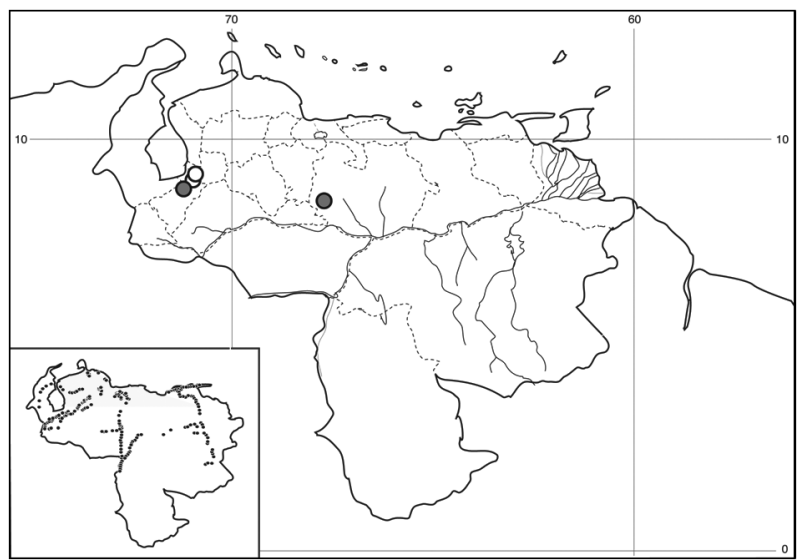

Fig. 4: distribution map of Lymnaea cousini (white circles) and Lymnaea columella (grey circles). Insert on the map shows all the sampling sites carried out between 2005-2009.

During this malacological survey, a fourth species, the exotic L. columella was also collected in a canal at El Valle, Mérida, at an altitude of $1,929 \mathrm{~m}$ (N8 38'40.3" W71 ${ }^{\circ}{ }^{\prime} 28^{\prime \prime}$ ) (Fig. 4) and in an irrigation canal at Corozo Pando, state of Guárico at an altitude of $63 \mathrm{~m}$ (N8 $37^{\prime} 2.4^{\prime \prime}$ W67 $\left.33^{\prime} 56.8^{\prime \prime}\right)$ (Fig. 4). Shells of the Vene-zuelan $L$. columella showed all the characteristics described by Paraense (1983) and Brown (1994): ovate shell with a short spire and pointed apex, a large last whorl about three times the length of the rest of the shell and the presence of characteristic minute spiral ridges of the periostracum (Fig. 1A, B). The most prominent anatomical features of $L$. columella are: (i) presence of a double flexure of the ureter; (ii) a thread-like to ribbonlike prostate; (iii) a preputium about 2-6 times as long as the penial sheath and (iv) a penial sheath apparently devoid of minute apical chambers (Fig. 7).

\section{Morphological identification of lymnaeids}

The members of the Lymnaeidae family exhibit a vast conchological diversity linked to substantial eco-phenotypic plasticity making a clear distinction between species difficult. This difficulty may explain why, until recently, only two species, L. cubensis and L. columella, have been reported in Venezuela (Lutz 1928, Briceño-Rossi 1950, Malek \& Chrosciechowski 1964, Pino \& Morales 1982, Morales \& Pino 1992). However, the recent discovery of a third species, $L$. cousini at very high altitudes in the Venezuelan Andes, is perhaps linked to the scarcity of malacological data from this area rather than an identification problem, as this $L$. cousini has a shell quite distinct from the other species (Pointier et al. 2004).

The use of anatomical characters of the reproductive system has proved very useful for the distinction between lymnaeid species in the Neotropical Area (Paraense 1976, 1982, 1984, 1995). These characters are particularly useful in separating the local $L$. cubensis from the European L. truncatula because conchological studies carried out on several populations of these two species, were unable to distinguish between them 

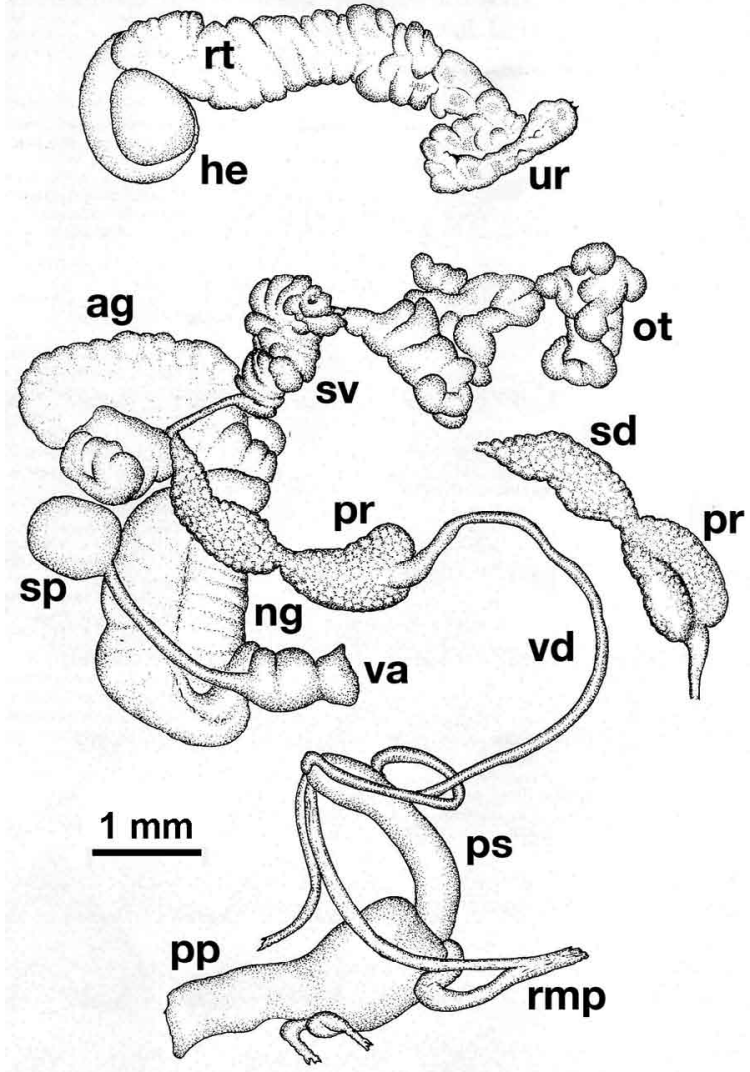

Fig. 5: anatomy of the reproductive system of Lymnaea cousini from Mucubaji, state of Mérida: ag: albumen gland; he: heart; ng: nidamental gland; ot: ovotestis; pp: preputium; pr: prostate; ps: penis sheath; rmp: retractor muscle of penial complex; rt: renal tube; sd: spermiduct; sp: spermatheca; sv: seminal vesicle; ur: ureter; va: vagina; vd: vas deferens. See the double flexure of ur, characteristic of $L$. cousini.

due to the large variability within and between populations (Samadi et al. 2000). In contrast, this study was able to clearly distinguish between the two taxa using characters of the male reproductive system. The validity of these anatomical markers has been confirmed by a genetic variability analysis based on 12 enzyme loci (Durand et al. 2002) and by the analysis of several DNA sequences such as the small subunit (18S) gene, internal transcribed spacers (1 and 2) and the cytochrome c oxidase subunit I (Bargues et al. 2007).

\section{Distribution of the lymnaeid snails in Venezuela}

The most prominent feature of our malacological survey is the discovery of 24 populations of the European $L$. truncatula in the Andinean Mérida and Táchira at an altitude varying between $1,540 \mathrm{~m}$ (Bodoque) and 4,000 $\mathrm{m}$ (Paso el Condor). These results confirm the invasion of $L$. truncatula into South America by which is now present in the Venezuelan Andes, the Altiplano Region of Bolivia and Peru (Mas-Coma 2005), the Argentinian Andes (Bargues et al. 2006) and the Valdivia area in Southern Chile (Yahia 1997). In Venezuela, the local species L. cubensis

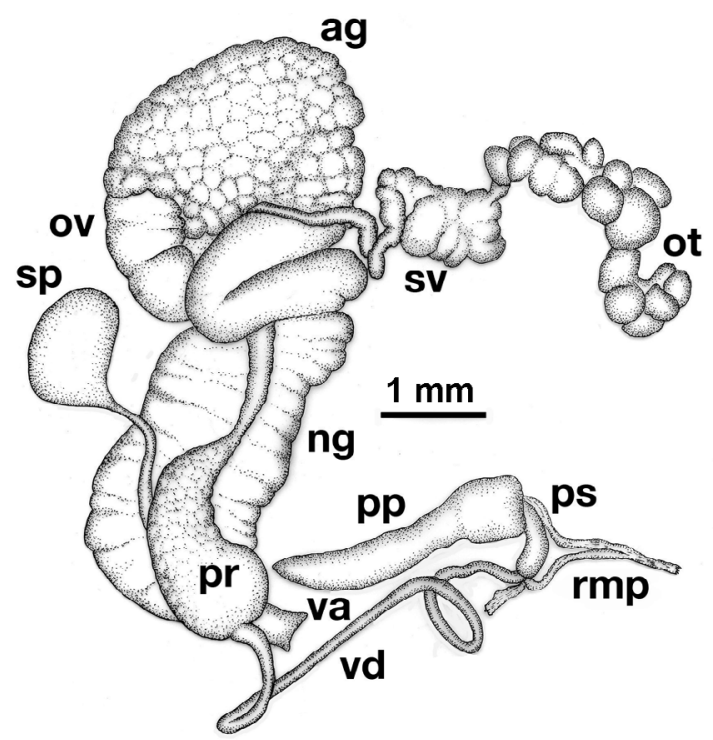

Fig. 6: anatomy of the reproductive system of Lymnaea truncatula from Mucuchies, state of Mérida: ag: albumen gland; ng: nidamental gland; ot: ovotestis; ov: oviduct; pp: preputium; pr: prostate; ps: penis sheath; rmp: retractor muscle of penial complex; sp: spermatheca; sv: seminal vesicle; va: vagina; vd: vas deferens.

is sporadically distributed across the whole northern part of the country from the oriental state of Sucre to the western of Trujillo in the Andes where the species reaches an altitude of $1,802 \mathrm{~m}$ at Mesa de Esnujaque. This last site is only about $10 \mathrm{~km}$ from Timotes, where $L$. truncatula was collected, but belongs to a different valley system. The respective distribution areas of L. cubensis and L. truncatula do not appear to overlap, but more detailed malacological surveys remain to be done in the Venezuelan Andes in order to see if a phenomenon of competitive exclusion occurs between the two species.

In Venezuela, L. cousini was collected at only two sites at a very high altitude $(3,550 \mathrm{~m}$ and $4,040 \mathrm{~m}$, respectively). This discovery confirms that this species is restricted to high altitude habitats in the northern part of the Andean chain. Currently L. cousini has only been reported from ponds of the type locality in Ecuador at a height of 2,950 m (Jousseaume 1887) or from several sites in Ubaque and Bogotá, Colombia, at heights between 2,066-2,650 m (Piaget 1912, Pilbry 1935, Velásquez 2006). The two Venezuelan sites harboured monospecific populations of $L$. cousini. In this region, the rarity of $L$. cousini coupled with the occurrence of a number of similar sites colonized by L. truncatula, could be interpretated as the result of competitive displacement due to the invasion by L. truncatula, but this hypothesis remains to be investigated.

The timing and origin of the introduction of $L$. truncatula in Venezuela are not known but molecular studies carried out on these lymnaeid populations may provide further information. Indeed, a study of the genetic diversity and population structure of $L$. truncatula samples collected from the Bolivian Altiplano has shown the presence of a single genotype. Several hypotheses have been 
TABLE II

Information on the 24 sites with Lymnaea truncatula sampled in Venezuela between 2005-2009

\begin{tabular}{|c|c|c|c|c|c|}
\hline Population name & State & Habitat & Coordinates & Coordinates & $\begin{array}{l}\text { Altitude } \\
\text { (m) }\end{array}$ \\
\hline Chachopo & Mérida & $\operatorname{tank}$ & N856'30.4'’ & $\mathrm{W} 70^{\circ} 45^{\prime} 3.8^{\prime \prime}$ & 2,516 \\
\hline Timotes & Mérida & ditch & N8 $8^{\circ} 57^{\prime} 50.2^{\prime \prime}$ & W7045'9.8', & 2,269 \\
\hline Timotes & Mérida & swamp & N857'54.3”' & W7045'11.1'” & 2,230 \\
\hline Rincon de la Venta & Mérida & ditch & N854'33.1', & W7047'6.6', & 3,073 \\
\hline El Sapo & Mérida & pond & N852’4’’ & W7048'29.3”' & 3,700 \\
\hline Paso el Condor & Mérida & ditch & N850’13.7', & W7049’48.6”' & 4,000 \\
\hline Paso el Condor & Mérida & brook & N850’49.1', & W7050’28.6" & 3,824 \\
\hline Santo Domingo & Mérida & ditch & N852’38.6”' & W70³9’41.6’' & 1,842 \\
\hline La Asomada & Mérida & ditch & $\mathrm{N} 8^{\circ} 49^{\prime} 49.5^{\prime \prime}$ & W70 $51^{\prime} 28.1^{\prime \prime}$ & 3,591 \\
\hline Valle Grande & Mérida & ditch & N840'18.4', & W716’9.9’’ & 2,146 \\
\hline Los Frailes & Mérida & ditch & N848'54.4', & W7047'10.5', & 2,974 \\
\hline Las Cruces & Mérida & ditch & N83' $14.4 \prime$ & $\mathrm{W} 71^{\circ} 20^{\prime} 25.5^{\prime \prime}$ & 2,021 \\
\hline Miraflores Alto & Mérida & pond & N836'52.6”' & W71²1’49’' & 2,343 \\
\hline San Eusebio & Mérida & ditch & N838’39”' & $\mathrm{W} 71^{\circ} 23^{\prime} 42.2^{\prime \prime}$ & 2,277 \\
\hline El Charota & Mérida & ditch & N840'16.3', & W71²4’36.4”' & 2,038 \\
\hline Bodoque & Mérida & ditch & N8¹6’14.9’' & W7148'51’' & 1,540 \\
\hline La Otra Banda & Mérida & ditch & N8॰14'5', & $\mathrm{W} 71^{\circ} 50^{\prime} 25.1^{\prime \prime}$ & 1,876 \\
\hline Tapias & Mérida & ditch & N8¹2’8’' & W71'50'14.3’” & 2,041 \\
\hline El Palmar & Táchira & ditch & N8¹3’2.7’', & W71 $51^{\prime} 41.4^{\prime \prime}$ & 2,142 \\
\hline La M & Táchira & ditch & N8¹3'44.6", & W71 ${ }^{\circ} 52^{\prime} 40.7^{\prime \prime}$ & 2,662 \\
\hline Pueblo Hondo & Táchira & ditch & N8 $8^{\circ} 15^{\prime} 14.4^{\prime \prime}$ & W71 ${ }^{\circ} 54^{\prime} 50.9^{\prime \prime}$ & 2,342 \\
\hline Llano Largo & Táchira & ditch & N8¹1'44.1", & W71'56'55" & 2,032 \\
\hline Pregonero & Táchira & canal & N8॰8'14.8', & W71 ${ }^{\circ} 56^{\prime} 22.3^{\prime \prime}$ & 2,199 \\
\hline Las Porqueras & Táchira & pond & N8 ${ }^{\circ} 9^{\prime} 4.2^{\prime \prime}$ & W71 $55^{\circ} 46.9^{\prime \prime}$ & 2,511 \\
\hline
\end{tabular}

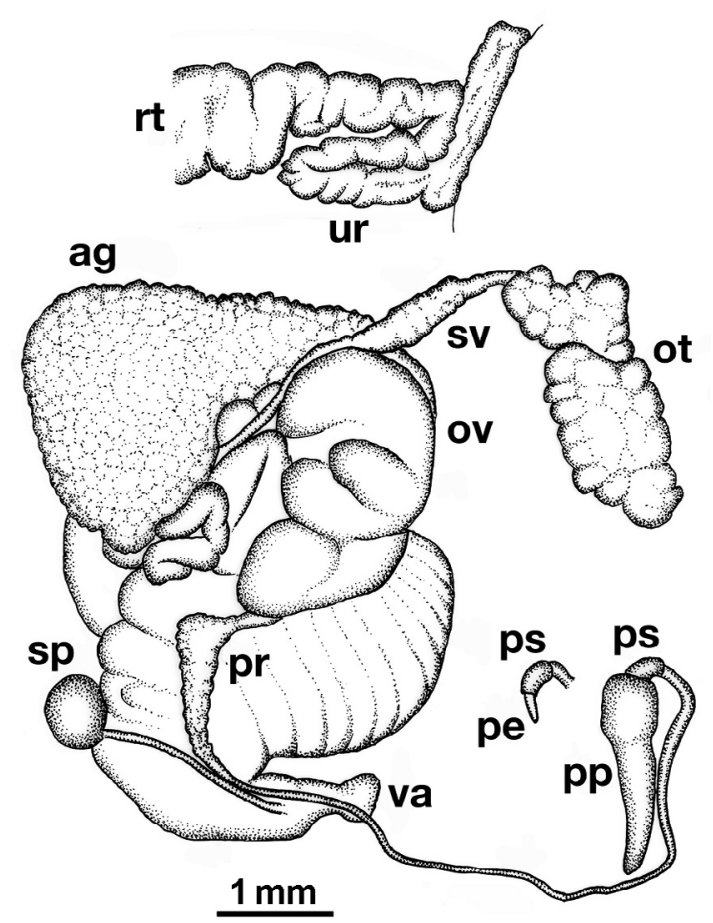

Fig. 7: anatomy of the reproductive system of Lymnaea columella from Corozo Pando, state of Guárico: ag: albumen gland; ot: ovotestis; ov: oviduct; pe: penis: pp: preputium; pr: prostate; ps: penis sheath; rt: renal tube; sp: spermatheca; sv: seminal vesicle; ur: ureter; va: vagina. See the double flexure of ur, characteristic of $L$. columella. discussed to explain this remarkable result and the most likely is that this species could have recently invaded the Bolivian Altiplano from Europe or from other areas of South America (Meunier et al. 2001). This hypothesis is supported by previous malacological surveys carried out in this area: the presence of lymnaeid snails on the Bolivian Altiplano was first reported by Ueno et al. (1975) and before that, lymnaeid snails were always absent from species lists made during surveys, the last being the Percy Sladen Trust Expedition of 1937 (Haas 1955).

A second exotic lymnaeid species, L. columella, presently occurs in Venezuela. This species was first reported in a canal in the city of Maracay, state of Aragua (Malek \& Chrosciechowski 1964) and its presence was confirmed at this site in 1996, as well in two other sites from the southern part of Valencia Lake, state of Carabobo (JP Pointer, O Noya, unpublished observations). However, recent surveys carried out in 2006 did not record $L$. columella from these sites. It seems that this species is now sporadically distributed in Venezuela and has been found from sea-level to high altitude, i.e., $1,929 \mathrm{~m}$ at El Valle, Mérida, in 2006.

L. columella probably originates from North America, but now has a worldwide distribution. During the XIX century, its distribution in the United States extended over the eastern and midwestern states as well as from Canada to the southern states (Baker 1928). At the beginning of the XX century, it was introduced to California and Oregon (Vanatta 1915, Greg 1923). It was then reported from 
Cuba and Mexico (Aguayo 1938) and enlarged its distribution area to Puerto Rico (Harry \& Hubendick 1964), Colombia (Malek \& Cogswell 1980), Brazil (Paraense 1982) and Argentina (Scott 1953). This snail was also introduced to Australia (Boray et al. 1985) and to several Pacific islands, such as Tahiti, Rapa, Tubuai and Rurutu (Pointier \& Marquet 1990, Gargominy \& Fontaine, personal communication). In 1942 it was first reported from South Africa and then from several other African countries (Appleton 2003). The presence of this species in Europe had been restricted to botanical gardens (Brown 1994) but it was recently discovered in the wild in Southern France (Pointier et al. 2007).

\section{Role of lymnaeid snails in the transmission of fascio- liasis in Venezuela}

The four lymnaeid species discovered at the present time in Venezuela are all susceptible to $F$. hepatica miracidial infection and their role as effective intermediate hosts has been demonstrated in several countries (Malek 1985).

L. cousini has recently been found naturally parasitized by $F$. hepatica in Machachi, Ecuador (Villavicencio \& Carvalho de Vasconcellos 2005), and in Paipa, Colombia (Velásquez 2006). However, as stated by MasComa (2007), its role in the transmission of $F$. hepatica is well known in Colombia from long ago (Brumpt et al. 1939-1940). Unfortunately, the role of $L$. cousini as an intermediate host of fascioliasis in Venezuela is not known but its apparent rarity suggests it has a negligible epidemiological importance.

The epidemiological situation seems similar to that of the introduced L. columella which is uncommon at the present time in Venezuela and which has never been reported naturally infected by $F$. hepatica in the field. However, all Venezuelan samples collected in this study are morphologically similar to susceptible phenotypes studied in Cuba, i.e., well rounded shell and characteristic mantle pigmentation pattern (Gutiérrez et al. 2003). Moreover, L. columella has been reported naturally infected by $F$. hepatica in several countries it has invaded, such as Australia (Boray et al. 1985), Brazil (Ueta 1980) and Argentina (Prepelitchi et al. 2003).

In Venezuela, fascioliasis is a serious problem for cattle and has been reported from several states such as Mérida (Vivas 1976), Trujillo (Morales \& Pino 1981), Lara, Yaracuy, Falcón, Portuguesa (Meléndez et al. 1983) and Zulia (Moreno \& España 1982). In all cases, L. cubensis was reported as the intermediate snail host transmitting the parasite to cattle. This study on the distribution of $L$. cubensis in Venezuela agrees with all these observations (Fig. 2), except for the highest parts of Mérida, where the most common lymnaeid snail is $L$. truncatula and not L. cubensis.

L. truncatula is the main snail host of human fascioliasis in the Old World and is responsible for the high prevalence and intensities which have been observed in humans in the Northern Bolivian Altiplano (Mas-Coma et al. 1999). In Venezuela, the occurrence of $L$. truncatula in the Timotes area where five positive children belonging to the same family were detected must be also emphasized (Alarcón de Noya et al. 2007). Consequently, the current presence of numerous L truncatula populations in the Venezuelan Andes must be now considered as a new potential risk not only for cattle, but also for humans. Epidemiological implications of the presence of L. truncatula for cattle and humans living in this area must be investigated in the future.

\section{ACKNOWLEDGEMENTS}

To Dr. Suzanne Mills, for helpful revision of the manuscript.

\section{REFERENCES}

Abdul-Hadi S, Contreras R, Tombazzi C, Alvarez M, Melendez M 1996. Hepatic fascioliasis: case report and review. Rev Inst Med Trop Sao Paulo 38: 69-73.

Aguayo CG 1938. Los moluscos fluviatiles Cubanos. Parte I. Generalidades. Parte II. Sistemática. Mem Soc Cub Hist Nat 12: 203-276.

Alarcón de Noya B, Rojas E, Colmenares C, Morales C, Contreras R, Valero SK, Hernández D, Briceño S, Scorza JV, Noya O 2007. Brote familiar de fascioliasis en Venezuela. Bol Malar Salud Amb 47: 47-54.

Alarcón de Noya B, Sosa VL, Colmenares C, Beker B, Contreras R, Meo PM 2006. Localización pancreática de Fasciola hepatica en un caso humano autóctono proveniente del Edo. Bolívar, Venezuela. Gen Rev Soc Venz Gastro 60: 134-137.

Appleton CC 2003. Alien and invasive freshwater Gastropoda in South Africa. Afr J Aquat Sci 28: 69-81.

Baker HB 1928. The freshwater mollusca of Wisconsin. Part I. Gastropoda, Wisconsin Acad Sci Art Let Monograph, Madison, $86 \mathrm{pp}$.

Bargues MD, Artigas P, Mera y Sierra RL, Pointier JP, Mas-Coma S 2007. Characterisation of Lymnaea cubensis, $L$. viatrix and $L$. neotropica n. sp., the main vectors of Fasciola hepatica in Latin America, by analysis of their ribosomal and mitochodrial DNA. An Trop Med Parasit 101: 621-641.

Bargues MD, Mera y Sierra RL, Gómez HG, Artigas P, Mas-Coma S 2006. Ribosomal DNA ITS-1 sequencing of Galba truncatula (Gastropoda, Lymnaeidae) and its potential impact on fascioliasis transmission in Mendoza, Argentina. An Biodiv Cons 29: 191-194.

Boray JC, Fraser GC, Williams JD, Wilson JM 1985. The occurrence of the snail Lymnaea columella on grazing areas in New South Wales and studies on its susceptibility to Fasciola hepatica. Aust Vet J 62: 4-6.

Briceño-Rossi A 1950. Trabajos experimentales sobre Fasciola hepatica. Primera comprobación del verdardero huésped intermediario de este parásito en Venezuela. Rev San Asist Soc 15: 381.

Brown DS 1994. Freshwater snails of Africa and their medical importance, Taylor \& Francis, London, 609 pp.

Brumpt E, Velasquez J, Ucroz H, Brumpt LCh 1939-1940. Mission E. Brumpt et L.Ch. Brumpt en Colombie et au Venezuela. 1. Découverte de l'hôte intermédiaire, Limnaea bogotensis Pilsbry, de la grande douve, Fasciola hepatica en Colombie. Ann Parasitol Hum Comp 17: 563-579.

Durand P, Pointier JP, Escoubeyrou K, Arenas JA, Yong M, Amarista M, Bargues MD, Mas-Coma S, Renaud F 2002. Occurrence of a sibling species complex within neotropical lymnaeids, snail intermediate hosts of fascioliasis. Acta Trop 83: 233-240.

Esteban JG, Flores A, Anglés R, Mas-Coma S 1999. High endemicity of human fascioliasis between Lake Titicaca and La Paz Valley, Bolivia. Trans R Soc Trop Med Hyg 93: 151-156. 
Greg WO 1923. Introduced species of Lymnaea in Southern California. Nautilus 37: 34.

Gutiérrez A, Pointier JP, Yong M, Sánchez J, Théron A 2003. Evidence of phenotypic differences between resistant and susceptible isolates of Pseudosuccinea columella (Gastropoda: Lymnaeidae) to Fasciola hepatica (Trematoda: Digenea) in Cuba. Parasitol Res 90: 129-134.

Haas F 1955. XVII. Mollusca: Gastropoda. In Percy Sladen Trust Expedition. Trans Linn Soc London 1: 274-308.

Harry HW, Hubendick B 1964. The freshwater pulmonate Mollusca of Puerto Rico. Göteborgs Kungl Vetens Vitters Handl 3: 1-93.

Incani RN, Vieira JM, Pacheco M, Planchart S, Amarista M, Lazdins $\mathrm{J}$ 2002. Human infection by Fasciola hepatica in Venezuela: report of a geriatric case. Invest Clin 44: 255-260.

Jabbour-Zahab R, Pointier JP, Jourdane J, Jarne P, Oviedo J, Bargues MD, Mas-Coma S, Anglés R, Perera G, Balzan C, Khallaayoune K, Renaud F 1997. Phylogeography and genetic divergence of some lymnaeid snails, intermediate hosts of human and animal fascioliasis with special reference to lymnaeids from the Bolivian Altiplano. Acta Trop 64: 191-203.

Jousseaume D 1887. Mollusques nouveaux de la République de l'Equateur. Bull Soc Zool Fra 12: 165-186.

Lutz A 1928. Estudios de zoología y parasitología venezolanas, Reimpreso UCV, Caracas, 1,955 pp.

Malek EA 1985. Snail hosts of schistosomiasis and other snail-transmitted diseases in Tropical America: a manual, PAHO, Washington, $325 \mathrm{pp}$.

Malek EA, Chrosciechowski P 1964. Lymnaea (Pseudosuccinea) columella from Venezuela, and notes on the distribution of Pseudosuccinea. Nautilus 78: 54-56.

Malek EA, Cogswell FB 1980. Lymnaea (Pseudosuccinea) columella in Colombia. Nautilus 94: 112-114.

Mas-Coma S 2005. Epidemiology of fascioliasis in human endemic areas. J Helminthol 79: 207-216.

Mas-Coma S 2007. Lymnaea cousini (Gastropoda: Lymnaeidae) as transmitter of fascioliasis. Mem Inst Oswaldo Cruz 102: 241-243.

Mas-Coma S, Anglés R, Esteban JG, Bargues MD, Buchon P, Franken M, Strauss W 1999. The Northern Bolivian Altiplano: a region highly endemic for human fascioliasis. Trop Med Int Health 4: 454-467.

Meléndez R, Coronado A, Diaz JY, Crespo G 1983. Aspectos epidemiológicos de la fasciolosis bovina en el centro-occidente venezolano con énfasis en la prevalencia del trematode y de su hospedador intermediario. Acta Cient Venez 34: 65-71.

Meunier C, Tirard C, Hurtrez-Boussès S, Durand P, Bargues MD, Mas-Coma S, Pointier JP, Jourdane J, Renaud F 2001. Lack of molluscan host diversity and the transmission of an emerging parasitic disease in Bolivia. Mol Ecol 10: 1333-1340.

Morales G, Pino L 1981. Lymnaea cubensis Pfeiffer, 1839: hospedador intermediario de $F$. hepatica en la zona alta de los Andes trujillanos. Bol Dir Malariol San Amb 21: 39.

Morales G, Pino L 1992. Fasciola hepatica: aspectos eco-epidemiológicos de interés para el desarollo de estrategias de control. In G Stagnaro (ed.), Ganadería mestiza de doble propósito, Ediciones Astro Data, Maracaibo, p. 301-329.

Moreno L, España W 1982. Parásitos gastrointestinales y $F$. hepatica en bovinos del asentamiento Las Majaguas, Estado Portuguesa. Vet Trop 7: 19-30.

Paraense WL 1976. Lymnaea viatrix: a study of topotypic specimens (Mollusca: Lymnaeidae). Rev Brasil Biol 36: 419-428.
Paraense WL 1982. Lymnaea rupestris $s p$. $n$. from Southern Brazil (Pulmonata: Lymnaeidae). Mem Inst Oswaldo Cruz 77: 437-443.

Paraense WL 1984. Lymnaea diaphana: a study of topotypic specimens (Pulmonata: Lymnaeidae). Mem Inst Oswaldo Cruz 79: 75-81.

Paraense WL 1995. Lymnaea cousini Jousseaume, 1887, from Ecuador (Gastropoda: Lymnaeidae). Mem Inst Oswaldo Cruz 90: 605-609.

Piaget J 1912. Voyage d'exploration scientifique en Colombie. Mem Soc Neuchatel Sci Nat 5: 265-269.

Pilsbry HA 1935. South American land and freshwater mollusks. IX. Colombian species. Proc Acad Nat Sci Philadelphia 87: 83-88.

Pino L, Morales G 1982. Hábitats de Lymnaea cubensis Pfeiffer, 1839, hospedador intermediario de Fasciola hepatica detectados en el Estado Trujillo, Venezuela. Acta Cient Venez 33: 61-65.

Pointier JP, Coustau C, Rondelaud D, Théron A 2007. Pseudosuccinea columella (Say, 1817) (Gastropoda, Lymnaeidae), snail host of Fasciola hepatica: first record for France in the wild. Parasitol Res 101: 1389-1392.

Pointier JP, Marquet G 1990. Taxonomy and distribution of freshwater mollusks of French Polynesia. Venus Jap J Mala 48: 147-160.

Pointier JP, Noya O, Amarista M, Théron A 2004. Lymnaea cousini Jousseaume, 1887 (Gastropoda: Lymnaeidae): first record for Venezuela. Mem Inst Oswaldo Cruz 99: 567-569.

Prepelitchi L, Kleiman F, Pietrokovsky SM, Moriena A, Racciopi O, Alvarez J, Wisnivesky-Colli C 2003. First report of Lymnaea columella Say, 1817 (Pulmonata: Lymnaeidae) naturally infected with Fasciola hepatica (Linnaeus, 1758) (Trematoda: Digenea) in Argentina. Mem Inst Oswaldo Cruz 98: 889-891.

Risquez JR 1929. Estado actual de la parasitologia en Venezuela. Gaz Med Caracas 25: 38-41.

Rodríguez A, González H 1975. Sobre un nuevo caso humano de fascioliasis hepática en Venezuela. Rev Inst Nac Hig 8: 111-114.

Samadi S, Roumégoux A, Bargues MD, Mas-Coma S, Yong M, Pointier JP 2000. Morphological studies of lymnaeid snails from the human fascioliasis endemic zone of Bolivia. J Moll Stud 66: 31-44.

Scorza JV, Villegas E, Morales C 1999. Fascioliasis hepática en el Estado Trujillo, Venezuela: un segundo caso clínico. Arch Venez Med Trop 3: 9-13.

Scott MIH 1953. Sobre limnaeidae argentinos. Physis 20: 401-408.

Ueno H, Arandia R, Morales G, Medina G 1975. Fascioliasis of livestock and snail host for Fasciola in the Altiplano Region of Bolivia. Natl Inst An Health Qua 15: 61-67.

Ueta MT 1980. Ocorrência de infecção natural de Fasciola hepatica Linnaeus, 1758 em Lymnaea columella Say, 1817, no Vale do Paraíba, SP, Brasil. Rev Saude Publica 14: 230-233.

Vanatta EG 1915. Lymnaea (Pseudosuccinea) columella in Oregon. Nautilus 29: 60.

Velásquez LE 2006. Synonymy between Lymnaea bogotensis Pilsbry, 1935 and Lymnaea cousini Jousseaume, 1887 (Gastropoda: Lymnaeidae). Mem Inst Oswaldo Cruz 101: 795-799.

Villavicencio A, Carvalho de Vasconcelos M 2005. First report of Lymnaea cousini Jousseaume, 1887 naturally infected with Fasciola hepatica (Linnaeus, 1758) (Trematoda: Digenea) in Machachi, Ecuador. Mem Inst Oswaldo Cruz 100: 735-737.

Vivas J 1976. Comprobación de distomatosis hepatica por Fasciola hepatica en huéspedes bovinos en la zona alta del páramo del Estado Mérida, Trabajo de Ascenso, Universidad de los Andes, Mérida, $126 \mathrm{pp}$.

Yahia H 1997. Biosystématique de mollusques Lymnaeidae, hôtes intermédiaires de la fasciolose en Amérique latine, DEA Biologie de l'Evolution et Ecologie, Montpellier, 24 pp. 